\title{
AKTIVITAS MINYAK SEREH WANGI SEBAGAI ANTI NYAMUK
}

\section{Citronella Oil Fragrants As Anti Mosquito}

\author{
Rd.Halim ${ }^{1}$, Adelina Fitri ${ }^{2}$
}

1,2 Program Studi Kesehatan Masyarakat
Fakultas Kesehatan Masyarakat Universitas Jambi

\begin{abstract}
Abstrak
Indonesia sebagai salah satu negara tropis di dunia dengan kelembaban udara yang cukup tinggi menjadi pemicu berkembang biaknya nyamuk seperti Aedes aegypti yang merupakan salah satu vektor DBD, Pada tahun 2017 jumlah penderita DBD di Indonesia yang dilaporkan sebanyak 129.650 kasus dengan jumlah kematian sebanyak 1.071 orang (IR/Angka kesakitan= 50,75 per 100.000 penduduk dan CFR/angka kematian=0,83\%). Dibandingkan tahun 2016 dengan kasus sebanyak 100.347 serta IR 39,80 terjadi peningkatan kasus pada tahun 2015. tanaman serai wangi menghasilkan minyak atsiri yang dikenal sebagai Citronella Oil. mengandung dua senyawa kimia penting yaitu Sitronelal dan Geranniol yang berfungsi sebagai pengusir nyamuk.Jenis Penelitian adalah penelitian Eksperimen Kuasi (Quasi Expriment) dengan rancangan Postest Only Control Group Design. Penelitian dilakukan di Laboratorium Kesehatan Lingkungan Fakultas Kesehatan Masyarakat Universitas Jambi. Sampel dalam Penelitian ini adalah minyak sereh wangi dari hasil penyulingan dengan sistem destilasi diformulasikan dengan VCO. Sampel nyamuk Aedes Aegypti dewasa dari hasil kembang biak nyamuk dari telur yang diperoleh dari Pusat Penelitian dan Pengembangan Kesehatan Baturaja Provinsi Sumatera Selatan dan. Jenis data yang dikumpulkan pada penelitian ini yaitu data hasil pengukuran jumlah gigitan nyamuk dan pemeriksaan komposisi minyak sereh wangi. Diperoleh Hasil Kompoisisi Minyak Sereh Wangi dengan kadar: Citronelal (39,7\%), Citronelol, (12,0\%) Geraniol (17,6\%). Jumlah rata rata nyamuk yang mengigit pada sampel kontrol 9,17, pada sampel perlakuan 0,17 , nilai proteksi sebesar $98,3 \%$. Terdapat perbedaan yang bermakna penggunaan formula minyak sereh wangi terhadap pencegahan gigitan nyamuk Aedes Aegypti. Formulasi minyak sereh wangi dapat diaplikasikan dan masyarakat dapat memanfaatkan pekarangan untuk ditanami sereh wangi.
\end{abstract}

Kata Kunci : Anti Nyamuk, Sereh Wangi

\begin{abstract}
Indonesia as one of the tropical countries in the world with high humidity is a trigger for the proliferation of mosquitoes such as Aedes aegypti which is one of the dengue vectors. In 2017 the number of dengue sufferers in Indonesia was reported as many as 129,650 cases with a total of 1,071 deaths (IRs) / Morbidity rate $=50.75$ per 100,000 population and CFR / mortality $=0.83 \%$ ). Compared to 2016 with 100,347 cases and IR 39.80 there was an increase in cases in 2015. The citronella plants produce essential oils known as Citronella Oil. contains two important chemical compounds namely Sitronelal and Geranniol which function as mosquito repellents. This type of research is a Quasi Experiment study with a Postest Only Control Group Design. The study was conducted at the Laboratory of Environmental Health, Faculty of Public Health, University of Jambi. The sample in this study was citronella oil from the distillation results with a distillation system formulated with VCO. Adult Aedes Aegypti mosquito samples from the breed of mosquitoes from eggs obtained from the Center for Health Research and Development of South Sumatra Province and South Sumatra. The type of data collected in this study is the result of measuring the number of mosquito bites and checking the composition of citronella oil. The results of the compilation of citronella oil with levels: Citronelal (39.7\%), Citronelol, (12.0\%) Geraniol (17.6\%). The average number of mosquitoes that bite in the control sample was 9.17 , in the treatment sample 0.17 , the protection value was $98.3 \%$. There is a significant difference in the use of the formula of citronella oil against the prevention of Aedes Aegypti mosquito bites. Lemongrass oil formulation can be applied and the public can use the yard to plant citronella.
\end{abstract}

Keywords : Anti Mosquito, Citronella Oil Fragrants

Korespondensi: Rd. Halim

Email: halim75@unja.ac.id 


\section{PENDAHULUAN}

Demam Berdarah Dengue (DBD) merupakan penyakit menular yang disebabkan oleh virus dengue dan ditularkan oleh vektor nyamuk Aedes aegypti dan Ae. Albopictus, tanda gejala demam $2-7$ hari disertai dengan manifestasi perdarahan, penurunan jumlah trombosit $<100.000 / \mathrm{mm}^{3}$, adanya kebocoran plasma ditandai peningkatan hematokrit $\geq 20 \%$ dari nilai normal. Pemeriksaan serologis (ELISA, Rapid Diagnostic Test/RDT Dengue) menunjukkan hasil positif. ${ }^{1}$

Demam Berdarah Dengue merupakan permasalahan kesehatan masyarakat utama di seluruh daerah tropis dan subtropis. Penyebaran penyakit ini terjadi secara cepat dengan peningkatan kejadian 30 kali lipat dalam kurun waktu 50 tahun terakhir. World Health Organization (WHO) memperkirakan 50-100 juta kasus infeksi terjadi setiap tahun dan hampir setengah dari populasi dunia berada di negara endemik. Saat ini sekitar $75 \%$ populasi global yang berisiko terpajan virus dengue berada di wilayah Asia-Pasifik. ${ }^{2}$

Angka terjadinya kasus DBD mengalami peningkatan secara drastis diseluruh dunia dalam beberapa tahun terakhir. Lebih dari 2,5 milyar penduduk didunia, lebih dari $40 \%$ nya beresiko mengalami DBD. Diperkirakan 50-100 juta orang di seluruh dunia terinfeksi demam berdarah dengue setiap tahunnya ${ }^{2}$.

Indonesia sebagai salah satu negara tropis di dunia dengan kelembaban udara yang cukup tinggi yang menjadi pemicu berkembang biaknya nyamuk seperti Aedes aegypti sehingga DBD mudah ditularkan melalui gigitan nyamuk Aedes aegypti. Hal tersebut menyebabkan masalah kesehatan karena terdapat banyak daerah endemik sehingga jumlah penderita semakin meningkat dan penyebaran pun semakin meluas ke wilayah lain dengan meningkatnya mobilitas dan kepadatan penduduk ${ }^{3}$.

Dalam 10 tahun terakhir, angka kesakitan juga mengalami fluktuasi. Dari 2008 hingga 2010 cenderung tinggi rata-rata di angka 60 per 100 ribu penduduk, lalu mengalami penurunan drastis pada 2011 sebanyak 27,67 per 100 ribu penduduk. Setelah itu, kecenderungan tren meningkat sampai 2016 menjadi 78,85 per 100 ribu penduduk dan kembali turun pada 2017 menjadi 26,12 per 100 ribu penduduk. ${ }^{4}$ Sementara Provinsi Jambi secara statistik mampu menekan angka kasus DBD hingga menjadi yaitu 39,80 per 100.000 tahun 2015, yang menempatkan Provinsi Jambi berada di atas target nasional. ${ }^{5}$

Sementara Kota Jambi merupakan daerah endemik dengan jumlah kasus DBD tertinggi di Provinsi Jambi. Sepanjang tahun 2016 jumlah kasus DBD di Kota Jambi adalah sebanyak 567 kasus. ${ }^{6}$ Penelitian DBD di Daerah Endemik Kota Jambi diperoleh Nilai House Index 30\%, Container Index 19,5\%, Breteu Index 46\% dan angka bebas jentik adalah $70 \%$. Terdapat hubungan bermakna antara variable letak container, suhu air, suhu udara, prilaku menyingkir barang bekas, Perilaku pemelihara ikan pemakan jentik, dan rumah dengan kawat kasa dengan variable keberadaan jentik. ${ }^{7}$ tingkat pengetahuan yang rendah dan perilaku Pemberantasan Sarang nyamuk (PSN) dan gerakan 3M-plus yang masih belum baik. ${ }^{8}$

Penggunaan obat anti nyamuk yang berasal dari bahan kimia mempunyai dampak positif dan negatif. Dampak positif yaitu dapat membasmi nyamuk sementara dampak negatif dapat menimbulkan polusi udara, menimbulkan bau yang menyengat dan bisa menimbulkan sesak nafas sehingga akan berpengaruh terhadap kesehatan. ${ }^{9}$

Saat ini, ada banyak jenis penolak nyamuk yang tersedia dan dijual bebas. Semprotan penolak nyamuk sangat umum dan mungkin disemprotkan pada pakaian atau kulit. Beberapa semprotan terbaik mengandung DEET dan konsentrasi tinggi efektif selama beberapa jam bahkan ketika berjalan melalui hutan di mana ada ribuan nyamuk. ${ }^{10}$

Penggunaan ekstensif insektisida sintetis selama lima dekade terakhir telah mengakibatkan bahaya lingkungan dan juga di pengembangan resistensi fisiologis pada spesies vektor utama. ${ }^{10}$ Meskipun demikian, nyamuk Penolak berdasarkan bahan kimia memiliki profil keamanan yang luar biasa, mereka beracun terhadap kulit manusia dan sistem saraf dan dapat menyebabkan ruam, pembengkakan, dan iritasi mata. ${ }^{11}$ Peningkatan jumlah penyakit yang ditularkan oleh nyamuk yaitu dengan melakukan 
kegiatan yang penting yaitu dengan melakukan pengendalian. Peningkatan jumlah nyamuk terjadi terutama disebabkan deforestasi, pertanian industri dan genangan air. ${ }^{12}$

Diperlukan produk senyawa khusus untuk penolak nyamuk kembali kepada zaman dahulu yaitu bahan alami. ${ }^{13}$ Insektisida nabati merupakan bahan aktif tunggal atau majemuk yang berasal dari tumbuhan yang bisa digunakan untuk mengendalikan organisme penggangu. Insektisida nabati ini bisa berfungsi sebagai penolak, penarik, antifertilitas (pemandul), pembunuh dan bentuk lainnya.

Secara umum insektisida nabati diartikan sebagai suatu insektisida yang bahan dasarnya dari tumbuhan yang relatif mudah dibuat dengan kemampuan dan pengetahuan terbatas. Pada umumnya insektisida nabati dapat dibuat dengan teknologi yang sederhana atau secara tradisional yaitu dengan cara pengerusan, penumbukan, pembakaran, atau pengepresan. ${ }^{14}$

Indonesia sebagai negara tropis memiliki keanekaragaman hayati penghasil minyak atsiri, sehingga berpotensi besar sebagai negara produsen penting dalam bisnis minyak atsiri dunia. Negara kita memiliki sekitar 40 jenis dari 80 jenis tanaman aromatik penghasil minyak atsiri yang diperdagangkan dunia. ${ }^{15}$

Tanaman Minyak atsiri menunjukkan aktivitas anti nyamuk yang lebih tinggi dibandingkan dengan tanaman ekstrak. Perbandingan tanaman yang dengan daya penolak nyamuk adalah dengan urutan Minyak atsiri sereh dan Minyak esensial Eucalyptus (100\%), Minyak Atsiri Tulsi (97,94\%,) Minyak Atsiri Cengkeh $(95,81 \%)$ Minyak atsiri Jeruk Manis (93,75\%) Minyak Atsiri Kunyit (89,56\%) Ekstrak Nika $(85,44 \%)>$ Ekstrak Neem $(81,25 \%) .{ }^{16}$

Salah satu Diantara tanaman sebagai bahan anti nyamuk adalah tanaman serai wangi (cymbopogon nardus) yang menghasilkan pati atau minyak atsiri yang dikenal sebagai Citronella Oil. Minyak Citronella mengandung dua senyawa kimia penting yaitu Sitronelal dan Geranniol yang berfungsi sebagai pengusir nyamuk. ${ }^{17}$ Herbal Tanaman serai terutama batang dan daunnya mengandung zat-zat seperti geraniol, metil heptenon, terpen-terpen, terpenalkohol, asam-asam organik dan terutama sitronelal yang bisa dimanfaatkan sebagai penghalau nyamuk. ${ }^{18}$

Penelitian Setyaningsih diperoleh bahwa efektivitas skin lotion sereh wangi memberi hasil negatif terhadap jumlah gigitan nyamuk. ${ }^{19}$ Reffelent atau Anti nyamuk adalah sesuatu zat yang diaplikasikan pada kulit, pakaian atau permukaan lain yang menghalangi nyamuk untuk mennempel pada permukaan tersebut. ${ }^{20}$ penolak nyamuk akan bekerja dengan cara menutupi atau melindungi kulit yang memiliki aroma atau dengan aroma yang dihindari nyamuk secara alami. ${ }^{20,21 .}$

Karbon dioksida dan asam laktat yang terdapat dalam keringat bertindak sebagai zat yang menarik bagi nyamuk. Persepsi rangsangan bau adalah melalui reseptor yang ada pada antena nyamuk. ${ }^{21}$ Zat Penolak memblokir reseptor asam laktat dan dihancurkan diterbangkan oleh angin. Oleh karena itu, nyamuk kehilangan kontaknya dengan Host. $^{20}$ Insektisida dan penolak berbasis kimia yang tersedia secara komersial diketahui mengandung senyawa berbahaya dan beracun yang dapat menimbulkan ancaman bagi kesehatan manusia dan toksisitas bagi organisme non-target. ${ }^{20}$

Penelitian telah menunjukkan efek insektisida dari produk tanaman, yang membuatnya cocok sebagai produk pengendalian hama yang aman. Minyak atsiri dari berbagai spesies tanaman telah digunakan sebagai penolak hama yang sangat efektif; seperti Cymbopogon nardus, Cymbopogon excavatus, Azaradicta indica, Eucalyptus maculata dll. ${ }^{22}$ perlunya penelitian dan pengembangan yang ramah lingkungan, biodegradable, murah, metode asli untuk pengendalian vektor yang dapat digunakan dengan perawatan minimum oleh individu dan masyarakat. $^{2}$

Berdasarkan latar belakang alternatif pencegahan penularan penyakit DBD yang melalui gigitan nyamuk aedes aegypti adalah dengan pemanfaatan tanaman alam yaitu sereh wangi maka penulis tertarik untuk melakukan penelitian "Aktivitas Minyak Sereh Wangi formulasi dengan VCO Sebagai Anti Nyamuk" 


\section{METODE PENELITIAN}

Jenis Penelitian ini adalah penelitian Eksperimen Kuasi (Quasi Expriment) dengan rancangan Postest Only Control Group Design. Penelitian dilakukan di Laboratorium Kesehatan Lingkungan Fakultas Kesehatan Masyarakat Universitas Jambi.

Alat dan bahan dalam penelitian ini adalah Tanaman Sereh wangi, minyak VCO, Blender, Cawan, Ember, Baskom, Jam Digital, Labu Erlemeyer, Pipet, Sendok, aspirator, Pisau, Meja Potong, kandang nyamuk, alat destilasi. Kapas, gunting, pisau, kertas saring, larutan gula, alkohol, aquadet dan lain lain.

Sampel dalam Penelitian ini adalah minyak sereh wangi dari hasil penyulingan dengan sistem destilasi uap. formulasi minyak sereh wangi dengan VCO sebanyak $70 \%$ dengan cara mencampurkan keduanya sampai homogen pada suhu kamar. Untuk sampel nyamuk Aedes Aegypti yang diperoleh dari proses kembang biak dari telur hingga menjadi nyamuk dewasa. Telur nyamuk Ae.Aegypti diperoleh dari Pusat Penelitian dan Pengembangan Kesehatan Baturaja Provinsi Sumatera Selatan. Untuk sampel kontrol negatif

Sampel Minyak Sereh wangi dilakukan pemeriksaan komposisi (Kadar Citronellal, Citronlellol, Geraniol).

Perlakuan Minyak Sereh Wangi dalam penelitian ini adalah dengan cara mengambil minyak sereh wangi yang sudah di formulasi dengan VCO sebanyak $\pm 2 \mathrm{ml}$ di oleskan ke seluruh lengan dan selanjutnya tangan dimasukkan ke dalam kurungan nyamuk berukuran $40 \times 30 \mathrm{~cm}$, yang berisi 20 sampel nyamuk $A e$. aegypti selama 5 menit. Selanjutnya melakukan perhitungan terhadap jumlah nyamuk yang menghisap darah. Percobaan ini dilakukan mulai dari pukul 08.00 WIB dengan interval waktu 30 menit dan mengulangi percobaan sebanyak 6 kali.

Perlakuan kontrol adalah tangan dimasukkan ke dalam kurungan yang berisi 20 ekor nyamuk Ae. aegypti selama 5 menit. Melakukan perhitungan terhadap jumlah nyamuk yang menghisap darah. Percobaan ini dilakukan mulai dari pukul 08.00 WIB dengan interval waktu 30 menit dan mengulangi percobaan sebanyak 6 kali.
Data yang dikumpulkan pada penelitian yaitu hasil perhitungan jumlah gigitan nyamuk dan pemeriksaan komposisi minyak sereh wangi. Analisis data menggunakan program SPSS, dengan uji T Test.

\section{HASIL DAN PEMBAHASAN}

Adapun hasil dari penelitian ini adalah untuk pengukuran kadar minyak sereh wangi dengan kadar Citronelal (39,7\%), Citronelol, $(12,0 \%)$ Geraniol $(17,6 \%)$.

Sementara hasil perhitunhan daya proteksi Minyak Sereh wangi terhadap gigitan nyamuk adalah pada tabel 1 .

Tabel 1. Hasil Perhitungan Daya Proteksi Minyak Sereh Wangi terhadap gigitan nyamuk Aedes Aegypti

\begin{tabular}{|c|c|c|c|c|}
\hline \multirow{2}{*}{ No } & \multicolumn{4}{|c|}{ Nyamuk yang Menggigit } \\
\cline { 2 - 5 } & $\begin{array}{c}\text { Sampel } \\
\text { Nyamuk }\end{array}$ & Kontrol & $\begin{array}{c}\text { Minyak } \\
\text { Sereh \& } \\
\text { VCO }\end{array}$ & Proteksi \\
\hline I & 20 & 9 & 0 & $100 \%$ \\
\hline II & 20 & 8 & 0 & $100 \%$ \\
\hline III & 20 & 8 & 0 & $100 \%$ \\
\hline IV & 20 & 11 & 0 & $100 \%$ \\
\hline V & 20 & 7 & 0 & $100 \%$ \\
\hline VI & 20 & 12 & 1 & $91,6 \%$ \\
\hline $\begin{array}{c}\text { Rata- } \\
\text { rata }\end{array}$ & & $\mathbf{9 , 1 7}$ & $\mathbf{0 , 1 7}$ & $\mathbf{9 8 , 3 \%}$ \\
\hline
\end{tabular}

Berdasarkan tabel 1. Dapat dilihat bahwa hasil perhitungan daya tolak nyamuk Ae.Aegypti terhadap aplikasi minyak sereh wangi selama enam kali pengulangan di peroleh bahwa pada tahap aplikasi pertama dan sampai aplikasi pengulangan keenam tidak terdapat jumlah gigitan nyamuk, sementara pada kontrol pada setiap aplikasi pengulangan pada perlakuan di dapatkan gigitan nyamuk dengan nilai paling sedikit nya 7 nyamuk yang menggigit dan paling banyak 12 nyamuk yang mengigit. Di lihat dari rata rata nilai diperoleh bahwa rata rata nyamuk yang menggigit adalah sebanyak 9,17 atau sebanyak 9 nyamuk yang menggigit sementara pada sampel minyak sereh adalah sebanyak 0,17 nyamuk yang mengigit artinya hampir tidak ada kejadian kasus menggigit pada responden. 
Untuk daya proteksi di peroleh bahwa untuk aplikasi minyak sereh wangi pada pengulangan pertama sampai dengan ke enam dengan proteksi $100 \%$ dan hanya pengulangan ke enam diperoleh proteksi 91,6\%. Jika dilihat dari total rata rata daya proteksi minyak sereh wangi adalah sebesar 98,3\%.

Tabel 2. Hasil Uji Statistik

\begin{tabular}{|l|c|c|c|c|c|}
\hline Variabel & Mean & SD & SE & $\mathbf{9 5 \%}$ CI & $\begin{array}{c}\text { P } \\
\text { Value }\end{array}$ \\
\hline Serai & 9,17 & 1,941 & 0,792 & $\begin{array}{l}7,13- \\
11,20\end{array}$ & 0,000 \\
\hline Kontrol & 0,17 & 0,408 & 0,167 & $\begin{array}{l}0,26- \\
0,60\end{array}$ & \\
\hline
\end{tabular}

Rata rata jumlah nyamuk yang tidak menggigit adalah sebesar 9,17 nyamuk dengan penggunaan formulasi minyak sereh wangi \& VCO. Hasil uji statistik menunjukan nilai $p$ Value : $0,000 \alpha 5 \%$ dapat disimpulkan bahwa ada perbedaan yang bermakna antara penggunaan minyak sereh wangi dengan formulasi VCO terhadap pencegahan gigitan nyamuk Ae.Aegypti.

Produk anti nyamuk yang mengandung insektisida DEET mempunyai daya penolakan nyamuk Aedes aegypti lebih tinggi dari beberapa jenis repellent yang dijual dipasaran. Disamping itu, kemampuan daya repellent juga tergantung dari jenis nyamuk yang menjadi sasaran ${ }^{18}$. Hasil ini juga menunjukkan hal yang sama dengan penelitian yang dilakukan di Kanada dimana secara keseluruhan repellent dengan DEET dan produk Avon Skin So Soft memberikan efek repellent lebih baik daripada bahan alami yaitu minyak ecalyptus. Akibat efek samping yang ditimbulkan dan ketakutan akan bahan kimia dari masyarakat, maka dikembangkanlah repellent dari bahan-bahan yang terdapat di alam, walaupun keefektifannya masih jauh dari harapan dibandingkan dengan repellent yang berbahan aktif DEET. Kemanjuran penolak kimia N, N-diethyl-3-methylbenzamide (DEET) dibandingkan produk lain membuatnya menjadi senyawa pilihan dalam pestisida ${ }^{23}$ Sementara ditinjau dari segi keamanan diperkirakan terdapat orang yang mengalami iritasi kulit, risiko terhadap kesehatan manusia dan lingkungan. Ketika pestisida terdaftar yang mengandung serai digunakan menurut label, tidak ada bahaya yang diperkirakan bagi manusia, hewan peliharaan atau lingkungan (US EPA 1999). Serai dapat memposting potensi toksisitas akut dan efek sublethal bagi penyerbuk dan serangga menguntungkan lainnya. ${ }^{24}, 25$ Minyak serai memberikan perlindungan antinyamuk selama 3 jam setelah upaya pendaratan dan gigitan dialami. Pengamatan ini akan menguatkan catatan volatilitas minyak atsiri tanaman sebelumnya. ${ }^{26}$

Hasil penyulingan dari serai wangi dapat diperoleh geraniol dan sitronelal yang dapat digunakan untuk menghalau nyamuk. Abu dari daun dan tangkai serai wangi mengandung silika yang merupakan penyebab dedikasi (keluarnya cairan dari tubuh serangga secara terusmenerus). Sitronelal dan geraniol merupakan bahan aktif yang tidak disukai dan sangat dihindari serangga, termasuk nyamuk sehingga penggunaan bahanbahan ini sangat bermanfaat sebagai pengusir nyamuk $^{9}$, hal ini disebabkan senyawa $\mathrm{CO} 2$ yang dihasilkan oleh kelenjar pada kulit manusia dapat dideteksi nyamuk melalui penciuman dan penglihatan.

Formulasi minyak Sereh wangi dengan VCO memberikan hasil sugestif untuk mempertimbangkan bahwa intensitas minyak dapat memiliki relevansi dengan waktu retensi perlindungan pada kulit. Terdapat satu gigitan yang dialami oleh sukarelawan pada jam perlakuan ke enam. Nyamuk-nyamuk yang menjauh dan menempel pada dinding kotak perlakuan, hal ini menujukan nyamuk-nyamuk tetap berada dalam pengaruh minyak sereh wangi dan Jelas bahwa semua nyamuk akan terbang menjauh dari sumber ketidaknyamanan (minyak) jika mereka tidak berada dalam kotak penangkaran.

Serai wangi dengan formulasi VCO merupakan salah satu jenis tanaman yang dapat digunakan sebagai anti nyamuk sesuai dengan syarat repellent yaitu tidak mengganggu pemakaiannya terbuat dari bahan alami tidak melekat atau lengket, baunya wangi, tidak beracun dan tidak menimbulkan iritasi pada kulit dan memanfaatkn lingkungan pekarangan serta mudah untuk dibudidayakan

\section{Kesimpulan dan Saran}


Jumlah nyamuk yang mengigit dengan perlakuan minyak sereh diperoleh nilai proteksi sebesar $98,3 \%$.

Terdapat perbedaan yang bermakna penggunaan formulasi minyak sereh wangi dengan VCO terhadap pencegahan gigitan nyamuk Aedes Aegypti.

Formulasi minyak sereh wangi dengan VCO dapat diaplikasikan kepada masyarakat.

Perlu pemberdayaan Kepada masyarakat memanfaatkan pekarangan untuk ditanami tanaman sereh wangi .

\section{DAFTAR PUSTAKA}

1. Kementerian Kesehatan RI, 2013, (Buku Saku Pengendalain DBD untuk pemegang Program DBD Puskesmas

2. WHO. 2012. Treatment, prevention and control global strategy for dengue prevention and control. Geneva: WHO Library Cataloguing Data.

3. Widoyono (2008) Penyakit Tropis (Epidemiologi, penularan, p[encegahan dan pembeantasannya Jakarta : Erlangga. PT. Gelora Aksara Pratama

4. Kementerian Kesehatan (2017) Info Datin Pusat data dan Informasi Kementerian Kesehatan, Situasi Penyakit DBD di Indonesia.

5. Kementerian Kesehatan Republik Indonesia. 2015. Profil Kesehatan Indonesia. Jakarta

6. (Laporan Dinkes Kota Jambi, 2017)

7. (Halim dkk. 2018) The Relationship among Environmental and Container Conditions, Mosquito Breeding Places Eradication Behaviors with The Existence of Aedes aegypti Larvae in Endemic Areas of Dengue Hemorrhagic Fever (DHF) in The City of Jambi, 2017.

8. Kalsum, U dan Halim. Identifikasi Tanda dan Gejala Kasus DBD Periode Januari-Maret 2017. Jurnal Khazanah Balitbangda Provinsi Jambi. Volume 1 no. 1 tahun 2017

9. Kardinan, 200).Tanaman Pengusir dan Pembasmi Nyamuk, Agro Media Pustaka, Jakarta

10. Chaiyakunapruk N., Kongkaew C., Sakunrag I., Tawatsin. Effectiveness of citronella reparations in preventing mosquito bites: systematic review of controlledlaboratory experimental studies. Tropical Med Int Health 2011; 16: 802-810.

11. Adeogun AO., Adewuyi GO., Etatuvie SO., Fawehinmi AB., Lawal HO. Bioassay of Herbal Mosquito Repellent Formulated from the Essential Oil of Plants. J Natprod 2012; 5: 109-115.

12. Pandey DM., Rani N., Vidyarthi AS., Wany A. Study of Citronella leaf based herbal mosquito repellents using natural binders. Curr Res Microb Biotechnol 2013; 1:98-103.

13. Adeniran OI., Fabiyi E. Natural products from plants as insecticides. J Nat Prod Plant Resour 2012; 2: 322-327

14. Kardinan A. 2001. "Pestisida Nabati Ramuan dan Aplikasinya".PT Penebar Swadaya. Jakarta

15. Agusta, A., 2000. Minyak atsiri tumbuhan tropika indonesia. Bandung: ITB Press.

16. Ranasinghe,et.al, Development of Herbal Mosquito Repellent Formulations, International Journal of Collaborative Research on Internal Medicine \& Public Health, Vol. 8 No. 6 (2016)

17. Flona. S, 2006, Herba dan Tanaman Hias, Penangkal Nyamuk dan Polusi Udara, Samidra Utama, Jakarta

18. Balitro. 2010. Wanafarma Melestarikan Hutan Dengan TanamanObat. Warta Penelitian dan Pengembangan Pertanian Vol.32/6. Bogor: Balitro.

19. Setyoningsih, Aplikasi Minyak Sereh wangi dan Geraniol dalam pembuatan skin lotion penolak nyamuk

20. Mandavgane, S. A., Pattalwar, V. V., and Kalambe, A. R. (2005). Development of cow dung based herbal mosquito repellent. Natural Project Radiance. 4(4): 270-273.

21. Pandey DM., Rani N., Vidyarthi AS., Wany A. Study of Citronella leaf based herbal mosquito repellents using natural binders. Curr Res Microb Biotechnol 2013; 1:98-103

22. Bhupen, K., Somi, B. and Sharma, A. K. (2013). Plant essential oils as mosquito repellent: A Review. International Journal of Research and Development in Pharmacy and Life Sciences. 3(1): 741-747. 
23. Fradin, M. S. and Day, F. J. (2002). Comparative efficacy of insect repellents against mosquito bites. New England J. Medicine, 347(1): 13-18

24. Xavier, Vania Maria, Dejair Message, Marcelo Coutinho Picanco, Leandro Bacci, Gerson Adriano Silva, and Jorgiane da Silva Benevenute. 2010. "Impact of Botanical Insecticides on Indigenous Stingless Bees (Hymenoptera: Apidae)." Sociobiology 56 (3): 713-725.

25. Xavier, Vania M, Dejair Message, Marcelo C. Picanco, Mateus Chediak, Paulo A. Sanatan Jr., Rodrigo S. Ramos, and Julio C. Martins. 2015. Acute toxicity and subletahl effects of botanical insecticides to honey bees. Journal of Insect Science, 15(1). https://doi.org/10.1093/jis-esa/iev110

26. Bhupen, K., Somi, B. and Sharma, A. K. (2013). Plant essential oils as mosquito repellent: A Review. International Journal of Research and Development in Pharmacy and Life Sciences. 3(1): 741-747.

27. Maia, Marta Ferreira, and Sarah J Moore. 2011. "Plant-Based Insect Repellents: A Review of Their Efficacy, Development and Testing." Malar J 10 (Suppl 1): S11. 